\title{
THE ROLE OF RELATIONSHIP MANAGEMENT IN THE SUCCESSFUL OUTSOURCING OF MAINTENANCE
}

\author{
A.J. van Niekerk ${ }^{1}$ and J.K. Visser $^{2}$ \\ ${ }^{1,2}$ Graduate School of Technology Management \\ University of Pretoria, South Africa \\ krige.visser@up.ac.za
}

\begin{abstract}
Outsourcing some maintenance functions (or the entire maintenance of specific equipment) is one of the options available to maintenance managers in managing their department more effectively. Several factors should be considered in establishing an outsourced maintenance relationship with the potential for long-term success. This paper discusses the results of an investigation into the role of relationship management in the success of maintenance outsourcing by users of production facilities. The results of a survey in the process industry reveal a strong correlation between successful outsourced maintenance and proper on-going management of the outsourcing relationship, and indicate that shortcomings in the management of the relationship are a prime driver of failed maintenance outsourcing.
\end{abstract}

\section{OPSOMMING}

Die uitkontraktering van sommige instandhoudingstake (of die totale instandhouding van spesifieke toerusting) is een van die opsies wat die instandhoudingsbestuurder kan oorweeg om 'n afdeling meer effektief te bestuur. Verskeie faktore moet in ag geneem word in die vasstelling van 'n uitkontrakteringsverhouding met die potensiaal vir langtermyn sukses. Hierdie artikel bespreek die resultate van 'n ondersoek na die rol van verhoudingsbestuur in die sukses van uitkontraktering van instandhouding deur gebruikers van produksiefasiliteite. Resultate van 'n steekproef in die prosesnywerheid toon 'n sterk korrelasie tussen suksesvolle uitkontraktering en kontinue bestuur van die uitkontrakteringsverhouding. Tekortkominge in die bestuur van die verhouding is dikwels die primêre oorsaak van mislukte uitkontraktering in instandhouding.

\footnotetext{
${ }^{1}$ The author was enrolled for the M Eng (Engineering Management) degree at the Graduate School of Technology Management, University of Pretoria.
} 


\section{INTRODUCTION}

Meyers [1] describes outsourcing of some maintenance functions (or the entire maintenance of specific equipment) as one of the 'tools' available to the maintenance manager. If this 'tool' is used correctly, it will continue to add more value to both the outsourcer and the outsourced maintenance provider.

Maintenance is a critically important function of any business that is dependent on physical assets for producing products or providing services. In certain cases there is a good business case for outsourcing some of the maintenance to an external party. Caspersen [2] feels that it is crucial for the maintenance outsourcing decision to be strategically correct, that the selected supplier must have a suitable organisation with skilled work force and the right equipment, and that the implemented outsourcing model must fit the situation. Even when all these requirements are met, the relationship sometimes fails.

This research project assessed the role that proper relationship management plays in ensuring that a correctly established outsourced maintenance relationship stays on the path to success, and remains a win-win encounter for both parties. The following aspects of outsourced maintenance were investigated:

- What is good outsourced maintenance?

- What management systems and elements need to be in place for maintaining a win-win outsourced maintenance relationship?

- What role does proper management of the outsourced maintenance relationship play in the success of the outsourced maintenance experience?

- What challenges in the South African business environment may threaten the success of outsourcing maintenance?

A literature study was performed to provide answers to the first two questions. A field survey was then conducted to verify these answers and to answer the last two questions. From the information obtained in the literature, definitions were developed for good maintenance and good outsourced maintenance. A relationship management framework for outsourced maintenance was also developed, verified, and used to indicate that insufficient and/or improper management of the relationship is a key factor in the failure of outsourced maintenance.

\section{RESEARCH APPROACH}

Ultimately good outsourced maintenance must lead to an improved bottom line for the outsourcer as well as for the maintenance service provider. A number of things can be done to ensure a successful long-term relationship. In order to identify these requirements, a literature study was conducted to review the knowledge areas of plant maintenance, business relationship management, and outsourcing. The aim of the literature study was to identify the following:

- What is good/successful outsourced maintenance?

- What are the essential elements for managing a sustainable win-win relationship in outsourcing physical asset maintenance?

The answer to the second question was used to develop a theoretical framework for successfully managing an outsourced maintenance relationship. The answers to these questions also formed the basis for a questionnaire that was used to conduct a survey through interviews with maintenance managers and maintenance service providers. The aim of the survey was to test the validity of the first two answers and to obtain answers for the following two questions: 
- What role does proper relationship management play in the success of maintenance outsourcing?

- What challenges unique to South Africa and relevant to such a relationship are experienced?

The survey focused on both successful and unsuccessful maintenance outsourcing experiences as case studies. The results of the survey were used to validate the theoretical work, and to provide evidence that mismanagement of the outsourcing relationship is a major cause of failed maintenance outsourcing.

\section{LITERATURE}

Patton [3] defines maintenance as 'the function of keeping equipment in, or restoring them, to a serviceable condition. It includes servicing, test, inspection, adjustment, alignment, removal, replacement, reinstallation, troubleshooting, calibration, condition determination, repair, modification, overhaul, rebuilding and reclamation'.

Production equipment maintenance is one of the major functions of any large asset intensive enterprise. Over the last 30 to 40 years, maintenance has developed from being reactive to proactive, and from being seen as a necessary evil into a strategic focus. In today's business environment, maintenance is becoming a profit center. Campbell [4] feels strongly that maintenance should be part of the life cycle management of a physical asset, and must be planned for in the early design phase of the asset.

Caspersen [2] says that maintenance should provide a comprehensive programme that includes the following aspects:

- A strategy aligned with business objectives

- Policies and plans to meet operational needs

- A suitable organisation with skilled work force and resources

- Performance measurement to ensure compliance with the plan

- An effective continuous improvement programme

Levery [5] advises that the maintenance function should be established as a service department with asset management responsibilities for maximising plant life, and as such should not be responsible to production; otherwise maintenance is reduced to 'fire-fighting' rather than continuous improvement. The goals and objectives of maintenance must, however, be aligned with the goals and objectives of production and the business in general.

Welch [6] suggests that maintenance can be categorised into six main elements:

- People

- Leadership

- $\quad$ Spare parts

- Tools \& technology

- Processes

- Costs

All of these elements must be addressed simultaneously to achieve sustainable success.

Bendor-Samuel [7] said that the maintenance of manufacturing plants includes three types of asset maintenance:

- Daily maintenance consisting of:

○ Routine

○ Preventive 


\section{- Predictive \\ - Proactive \\ - Corrective}

- Improvement maintenance

- Turnaround maintenance

Each of these three types requires different strategies, capabilities, resources, and planning.

Levery [5] feels that business management is only concerned most often with the immediate cost of maintenance. This is especially true when the plant is performing reliably and competitive pressures are felt. A focus on reducing the maintenance budget is however misplaced: it is short-term, and will most often lead to an increase in total cost in the longer term. Levery [5] also indicates that the total cost of bad/inadequate maintenance is mostly hidden, and consists of:

- Excessive spares inventories

- Accelerated depreciation of capital investments

- Excessive capital investment through redundancy

- Wasted production operator time

- Inability to produce at maximum rate

- Scrap and rework

- Poor quality and reliability of product

- Failure to meet delivery targets

- Lost reputation and current/future sales

Many maintenance approaches or strategies have been developed, such as Reliability Centered Maintenance (RCM), Total Quality Maintenance (TQMain), Total Productive Maintenance (TPM), and Business Centered Maintenance (BCM). Sherwin [8] discusses these approaches. They have been applied with varying success by many businesses. The most recent approach is to see all of these strategies as tools in the maintenance toolbox; the challenge is to integrate their use and apply them in the correct place, order, and manner. The fact that both operations and maintenance play a significant role in the maintenance of physical assets is well recognised. Levery [5] also finds that the relationship between production and maintenance is often quite delicate.

\section{THEORETICAL FRAMEWORKS}

This study on outsourcing maintenance required a theoretical framework that was developed from the available literature and practical experience. Inputs in the development of the framework were elements of good maintenance, good outsourced maintenance, and the client/service provider relationship.

\subsection{Good maintenance}

From the literature study it was clear that good outsourced maintenance must include all the attributes of good in-house maintenance and more. The following ten attributes describing good maintenance were identified:

- Strategic focus

- Integrated approach

- Suitable organisation

- Performance focused

- Effective

- Continuous improvement

- Value adding 
- Long term budget view

- Proactive

- Asset life time focused

\subsection{Good outsourced maintenance}

Bendor-Samuel [7] states that the primary benefit of outsourcing is the creation of value. With this in mind, as well as the realisation that value is more than just money, ten additional attributes describing good outsourced maintenance were identified:

- Better availability of equipment

- Better reliability of equipment

- Lower cost of maintenance

- Better safety record

- Improved environmental performance

- Sustainability of good performance

- More value created

- Sustainability of service

- Growth of maintenance capacity

- Better continuous improvement

\subsection{Framework for a win-win maintenance outsourcing relationship}

Byham [9] regards outsourcing as the process through which a business allocates some activity that it would be capable of doing in-house to an external provider. It is a long-term relationship between supplier and beneficiary, with a high degree of risk-sharing, and should not be confused with contracting out, which refers to work assigned to an outside supplier on a job-by-job basis (also see Embleton [10]).

\subsection{Elements for successful management of outsourcing relationship}

Twenty-two essential elements for successful management of a win-win maintenance outsourcing relationship were extracted from the literature study. A study of these elements revealed five management systems that must be in place and properly executed on an ongoing basis. The five essential management systems are:

- A system to sustain support

- A system to maintain team unity

- A system to manage performance

- A system to manage relationship wellbeing

- A system to ensure cohesion

These five systems are shown schematically in Figure 1.

The Support Retention System is essential to ensure that all the other aspects of the relationship continue to receive the appropriate amount of support and attention, and that there will be a force that drives the continued success of the relationship.

The Team Unity System is critical to prevent misalignment, and to ensure that the soft issues that are so important in good relationships are taken care of.

The Relationship Health Management System is required to identify and eliminate proactively any unintentional disagreements before the relationship suffers any damage that could have been prevented.

The Performance Management System is crucial, since it regulates the perceived fairness of the engagement. It is also the win-win indicator. It must be as objective as possible, and be well-aligned with the objectives of both parties. 


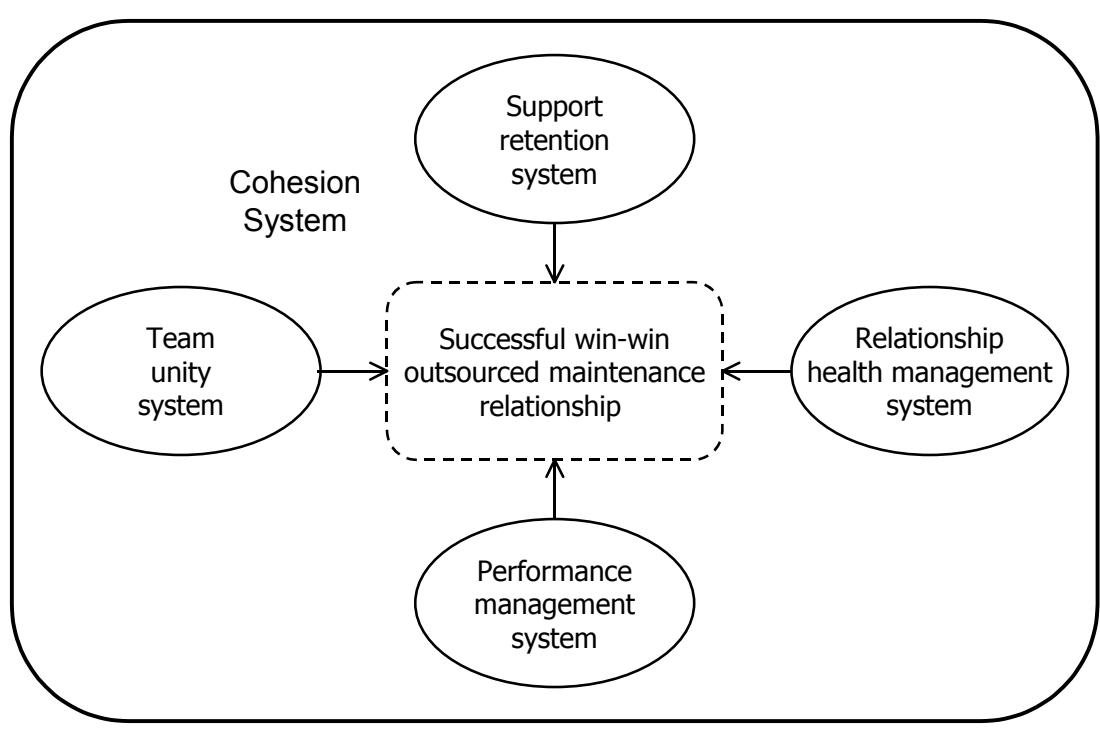

Figure 1: Outsourced maintenance relationship management framework

The Cohesion System encircles the other systems, and is required to ensure that all the other systems remain operational throughout the life of the relationship. It is the glue that keeps the other systems together. It consists of mechanisms to manage change, to ensure regular communication on all levels, and to ensure continued commitment.

The five essential management systems and twenty-two basic elements of outsourced maintenance are shown in Table 1 below.

\begin{tabular}{|l|l|}
\hline $\begin{array}{l}\text { Management } \\
\text { system }\end{array}$ & Basic elements \\
\hline $\begin{array}{l}\text { Support } \\
\text { retention } \\
\text { system }\end{array}$ & $\begin{array}{l}\text { Support from top management } \\
\text { Clear, agreed roles and responsibilities } \\
\text { Suitable organisation with skilled people and the required resources } \\
\text { Maintenance strategy aligned with client's business objectives } \\
\text { Maintenance policies and plans that meet client's operational needs } \\
\text { Accountability on both sides }\end{array}$ \\
\hline $\begin{array}{l}\text { Team unity } \\
\text { system }\end{array}$ & $\begin{array}{l}\text { Shared vision } \\
\text { Common goals } \\
\text { Shared expectations } \\
\text { Joint planning and review } \\
\text { Shared responsibility for success } \\
\text { Shared risk and reward }\end{array}$ \\
\hline $\begin{array}{l}\text { Performance } \\
\text { management } \\
\text { system }\end{array}$ & $\begin{array}{l}\text { Objective performance measurement } \\
\text { Incentives/remuneration that drive improvement } \\
\text { Effective continuous improvement programme }\end{array}$ \\
\hline $\begin{array}{l}\text { Relationship } \\
\text { health } \\
\text { management } \\
\text { system }\end{array}$ & $\begin{array}{l}\text { Relationship wellbeing assessment } \\
\text { Profitability for both partners } \\
\text { Mechanism to identify and reconcile differences } \\
\text { Clear contingency plan and exit strategy }\end{array}$ \\
\hline $\begin{array}{l}\text { Cohesion } \\
\text { system }\end{array}$ & $\begin{array}{l}\text { Change tracking and update mechanism } \\
\text { Regular communication } \\
\text { Collaboration agreement/commitment }\end{array}$ \\
\hline
\end{tabular}

Table 1: Essential systems and elements of an outsourced maintenance relationship 
For the framework to be effective in delivering a sustained win-win relationship, the basic elements given in Table 1 must be in place, sufficiently established, and well and regularly maintained.

\section{SURVEY DESIGN}

A survey was done to test the opinion of a number of individuals within organisations in the process industry. The following criteria were used in selecting candidates for interviews:

- Client is a South African operation and user of heavy equipment

- Business success of client reliant on equipment performance

- Maintenance outsourced directly impacts the availability of critical equipment

- Outsourcing relationship is older than one year, or failed

- Holds management position and is responsible for the outsourced maintenance

- Outsourcing supplier has/had suitable organisation with skilled staff

- The outsourcing decision must have been strategically correct

These requirements resulted in a limited choice of local companies. In order to ensure that enough good data was gathered, the field survey was conducted through personal interviews with maintenance managers and outsourcing provider relationship managers.

\section{DISCUSSION OF RESULTS}

Eleven personal interviews were conducted over a period of about one month. During these interviews, data was gathered and analysed on eleven successful and seven unsuccessful outsourced maintenance cases. Only the most important results are presented in this paper; the detailed results are available from Van Niekerk [11].

\subsection{Good maintenance}

The essential attributes of good maintenance that were identified through the literature study were confirmed by the survey. From the list of additional attributes of good maintenance identified by the interviewees, the following can be added to the ten originally identified to improve the description of good maintenance:

- Well-planned and executed

- Reliability/availability focused

- Well-supported by effective management systems

The definition of good maintenance could thus be formulated as:

- Effective, pro-active, and value-adding

- Reliability- and performance-focused

- Well-planned and executed by a suitable organisation with skilled people and the right equipment

- Well integrated with operations, and aligned with technical and procurement functions

- Supportive of the business strategy and part of each phase of the asset life cycle with a longer term budget view, and

- Well-supported by effective management systems, and continuously improving

\subsection{Good outsourced maintenance}

The survey indicated clear support for the following attributes that affect outsourcing of maintenance:

- Sustainability of good performance

- More value created for both parties 
- Sustainability of the service

- Continuous improvement

The other attributes were considered less essential, with the explanation that outsourced maintenance would often be considered to be good only if it maintains the availability, reliability, cost, safety, and environmental performance of the previously successful inhouse effort.

The following additional attributes were identified, and should be added to the list of originally identified elements to improve the definition of good outsourced maintenance:

- Win-win long-term partnership

- Supportive business case

- Good contract

The definition of good outsourced maintenance could thus be formulated as:

Good outsourced maintenance is good maintenance performed by an external party where:

- The relationship is a win-win partnership that creates more value for both partners

- The service is sustainable over the long term, and renders sustained good performance, and

- It leads to a growth in the maintenance capacity of the client, and enables continuous improvement

\subsection{Importance of elements for managing the outsourcing relationship successfully}

Respondents were asked to indicate the importance of the 22 basic elements (Table 1 ) on a scale of Low (not essential), Medium (essential), or High (critically essential). The results are summarised in the bar chart in Figure 2 below.

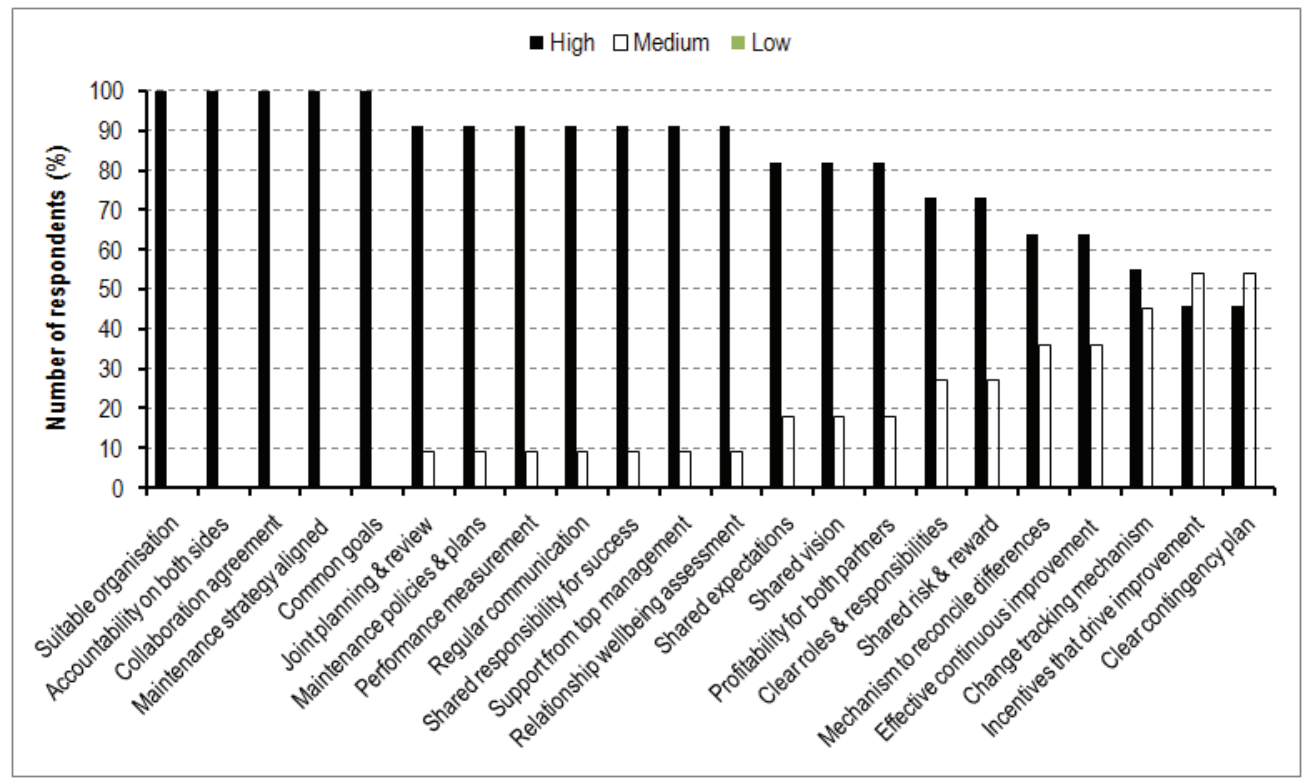

Figure 2: Importance of the basic elements of successful outsourced maintenance

It is clear from the $100 \%$ rating by all respondents that the critically essential elements of a win-win relationship are: 
- Suitable organisation with skilled people and the required resources

- Accountability on both sides

- Collaboration agreement and commitment

- Maintenance strategy aligned with client business objectives

- Common goals

As seen in Figure 2 above, none of the respondents rated the importance of any element as Low.

The data for the 22 basic elements shown in Figure 2 was also combined for the five management systems. The relative importance of these five systems is shown in Figure 3.

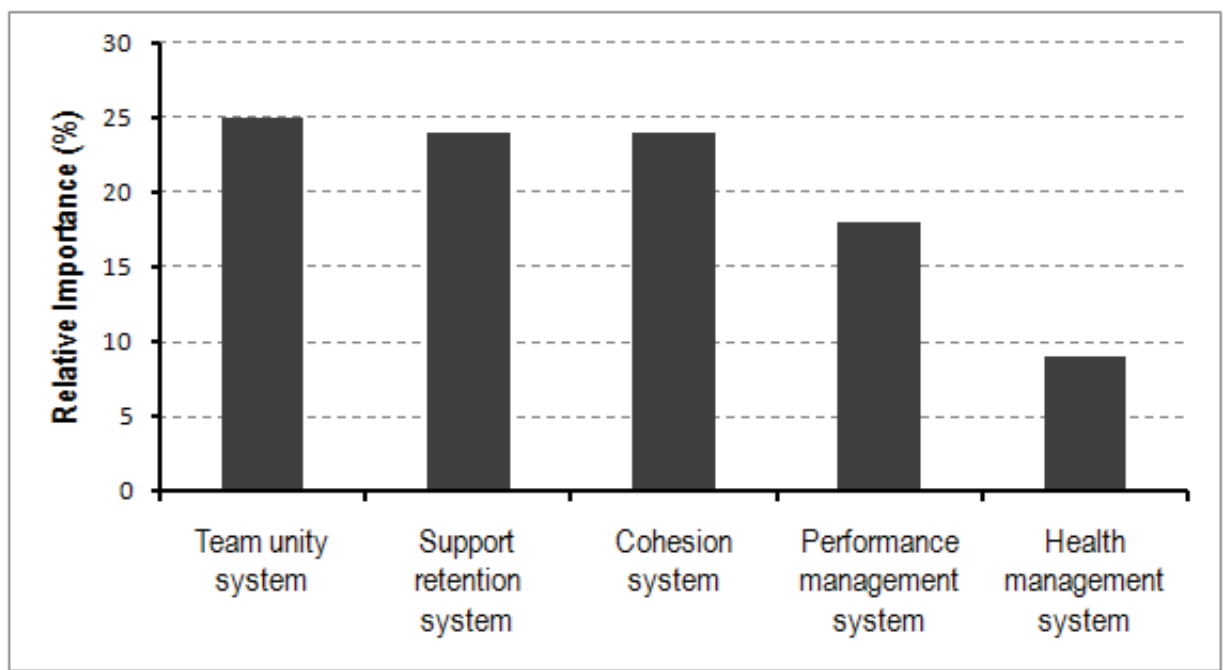

Figure 3: Importance of the management systems for successful outsourced maintenance management

It is clear from Figure 3 that the respondents saw the Team unity, Support retention, and Cohesion systems as the most important management systems.

\subsection{Good and bad outsourcing case analysis}

The survey questionnaire also tested each outsourced maintenance case, good or bad, for the presence of the 22 basic elements of the five management systems that form the relationship management framework. Where the presence of a basic element was confirmed during the interview, that element scored one point; and if the element was sufficiently in place, another point was allocated. The total score for each basic element for both good and bad relationships was calculated as the sum of individual scores. The graph in Figure 4 indicates the total scores for each of the 22 elements for good and bad relationships respectively.

From Figure 4 it is clear that there is a significant difference between good and bad outsourced maintenance experiences with respect to the level of management of the relationship. The essential elements for managing the relationship were clearly better established in the good relationships. This supports the research postulate that ineffective and/or insufficient management of the relationship is a main contributor to failed outsourced maintenance. 


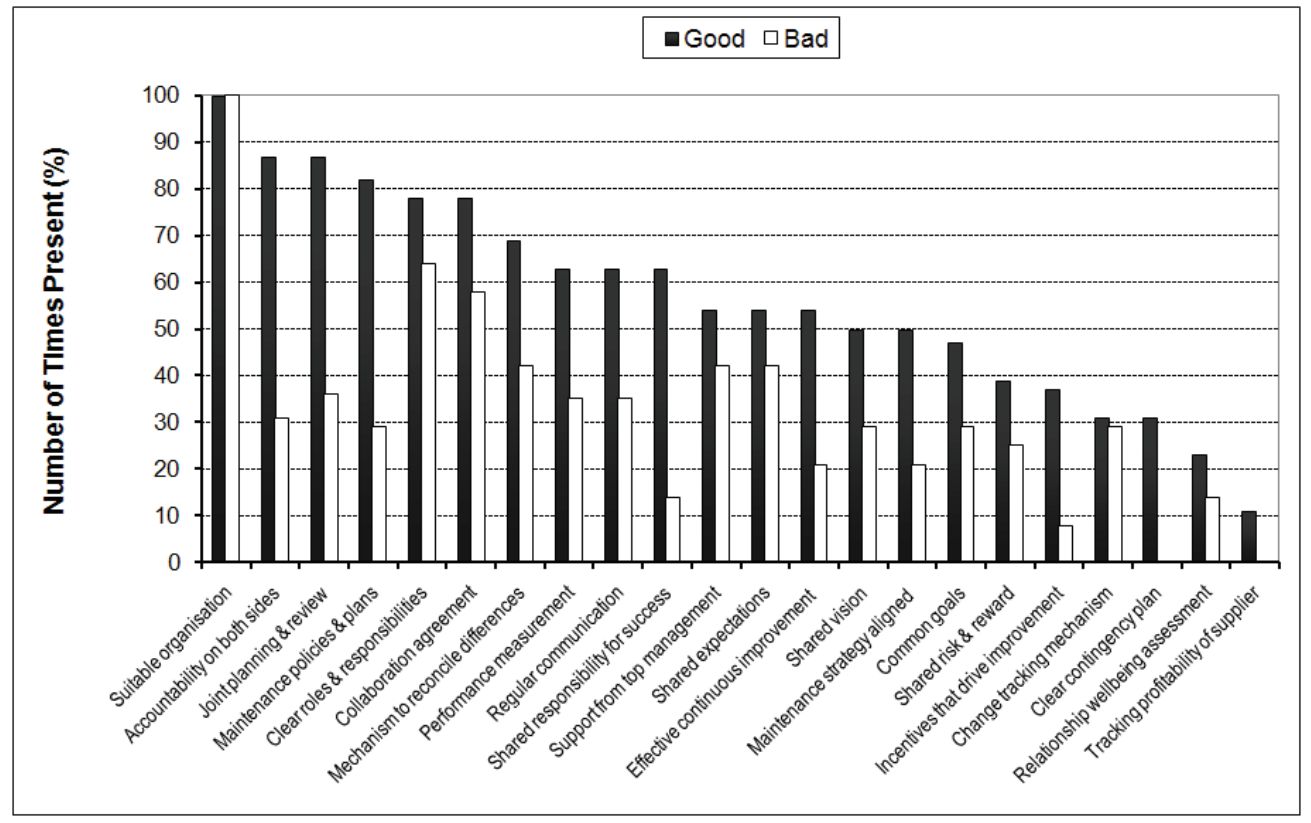

Figure 4: Difference between good and bad experiences

It is revealing that the biggest difference between good and bad experiences was in the tactical execution (day-to-day management) elements of the support and unity systems, namely:

- Accountability on both sides (for outcomes)

- Joint planning and review

- Maintenance policies and plans to meet operational needs

- Shared responsibility for relationship success

This particularly strengthens the validity of the research postulate that insufficient management of the relationship is a main contributor to failed outsourced maintenance. A general lack of management was evident in most of the bad cases.

There were, however, a few cases where most basic elements were in place, and yet the relationship still failed. In each of those cases the failure was attributed to a lack of sustained real commitment from one of the parties, and thus a failure in the cohesion system.

The same scoring system was also used to determine the extent to which each of the five systems of the framework was in place for both the good and the bad relationships. The score for each system is the average for the elements comprising that system. The graph in Figure 5 indicates the relative presence of each system (a score of 100\% means that all elements of that system were sufficiently present for all cases).

The graph in Figure 5 indicates that, for all five management systems, there was a higher presence of the essential elements in the good experiences versus the bad experiences. The presence of these essential elements of the outsourcing relationship is no guarantee that the relationship will be successful, but it certainly improves the likelihood of success.

\section{CONCLUSIONS}

This research identified the most important attributes of good outsourced maintenance, 
and the essential elements for managing outsourced maintenance in the process industry. The definitions and attributes of good maintenance and good outsourced maintenance given in this paper should enable maintenance managers of asset-intensive plants in the process industry to determine the quality of their outsourced maintenance, and to set goals for improvement where required.

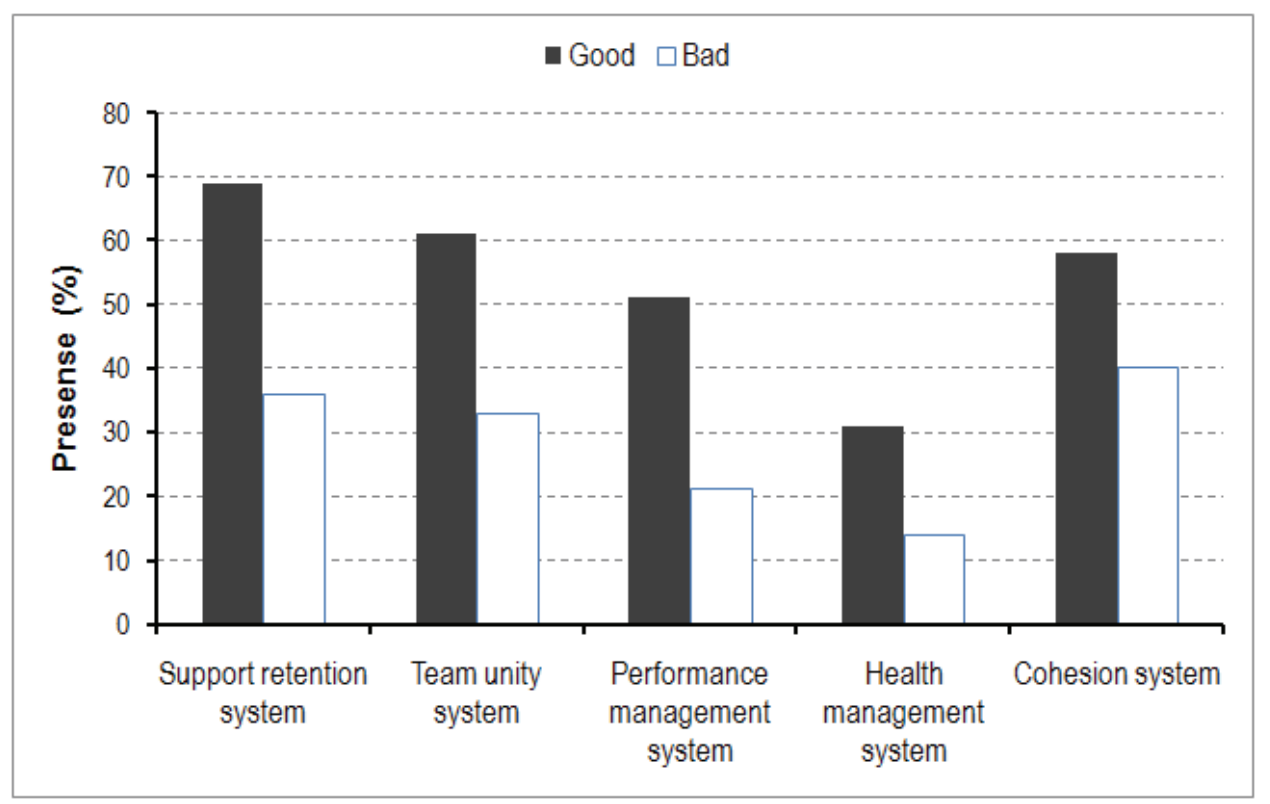

Figure 5: Presence of systems in good and bad outsourced maintenance experiences

The survey revealed that maintenance outsourcers in asset-intensive industries in South Africa are currently looking for longer-term value from their outsourcing relationships. They expect steady, dependable relationships with sustained good performance and steady longterm improvement. The focus is not on immediate improvements in results such as cost and reliability, although these results are also important.

The survey's strong support for the 22 identified essential elements for managing outsourced maintenance confirmed the validity of the proposed relationship management framework, and therefore also the use of these elements to test the level of relationship management present for good and bad outsourcing experiences.

Although the cohesion system seems to be the most critical for keeping the relationship alive, the support and unity systems are the foundation systems determining the health of the relationship. This was confirmed by the survey, where the biggest difference between good and bad experiences was recorded for elements of these systems.

The survey clearly indicated that the level of management present for unsuccessful outsourcing experiences was significantly lower than for successful experiences. This confirms that proper ongoing management of the relationship is required for long term success - in other words, that insufficient and/or improper management of the outsourced maintenance relationship is a main contributor to failed outsourced maintenance.

The survey identified a general lack of certain important relationship management elements in both the good and the bad experiences it analysed. Maintenance managers should take note of these shortcomings, and update their existing contracts accordingly.

The proposed framework for managing the outsourced maintenance relationship towards a 
win-win long-term partnership is simple and clear, and should promote understanding of the process required; while the identified essential elements provide a practical mechanism to pinpoint shortcomings in the relationship. Effective implementation and maintenance of each of the identified system elements should deliver the vision of a long-term win-win partnership.

A limitation of the project described in this paper is that only a small number of respondents could be found in the available time, and that only the process industry was involved. Process plants are unique in their continuous operation of equipment, which is not always the case with assembly plants and other types of systems. It is therefore recommended that a larger sample from different industries be used for a more generalised overview and conclusion.

\section{REFERENCES}

[1] Meyers, J.T. 2004. Why companies outsource services: Opportunities and challenges, Plant Engineering, December 2000, http:/ / oeiwcsnts1.omron.com/pdfcatal.nsf

[2] Caspersen, B. 2004. Siemens energy automation: Outsourcing maintenance, Plant Engineering, Dec 2000, www.ensil.com

[3] Patton, J.D. 1988. Maintainability and maintenance management, $2^{\text {nd }}$ edition, Instrument Society of America, North Carolina, USA.

[4] Campbell, J. 1995. Uptime: Strategies for excellence in maintenance, Productivity Press, Portland, USA.

[5] Levery, M. 2004. MCL Consultancy Ltd: Maintenance - organisational misfit? www.mclconsultancy.co.uk/pdf/orgmissjan97.pdf

[6] Welch S. 2004. Advanced technology services: A plan for success, www.plantmaintenance.com/articles/OutsourcingPlan.pdf

[7] Bendor-Samuel, P. 2004. The three dimensions of value, April 2002, www.outsourcing-best-practices.com/existing.html

[8] Sherwin, D. 2000. A review of overall models for maintenance management, Journal of Quality in Maintenance Engineering, 6 (3), pp 138-164.

[9] Byham, W.C. 2004. Development Dimensions International: The outsourcing question, www.ddiworld.com/pdf/WPOUTSO.pdf

[10] Embleton, P.R. \& Wright, P.C. 1998. A practical guide to successful outsourcing, Empowerment in Organizations, 6 (3), pp 94-106.

[11] Van Niekerk, A.J. 2005, The role of relationship management in the successful outsourcing of production critical maintenance in a physical asset intensive environment, M. Sc. Research Project Report, University of Pretoria. 